\title{
Sosialisasi Bahaya Narkoba Bagi Anak Muda
}

\author{
Yudhy Sanjaya $^{1 *}$, Manahan Uji Simanjuntak ${ }^{2}$, Go Heeng ${ }^{3}$, Susilo Susanto ${ }^{4}$, Ervi Johan \\ Lo $^{5}$, Josanti ${ }^{6}$, Agiana Her Visnhu Ditakristi ${ }^{7}$ \\ 1,3,4,5, 6 Prodi Teologi, STT REAL Batam \\ ${ }^{2,7}$ Prodi PAK, STT REAL Batam \\ *yudhysanjaya.ys@gmail.com
}

\begin{abstract}
The danger of drugs is very real where this is very troubling among teachers or lecturers from educational institutions. Many young people are victimized and if left unchecked it will damage the younger generation which will certainly threaten the life of the nation in the future. Prevention needs to be done. The influence of the use of these prohibited substances can harm the user both for the health of the body and ruster and mental. It can even lead to death. There needs to be an effort to find out why drug use is actually a lot among the younger generation or students. Therefore, this journal was compiled with the hope that it can be a driver for many parties to make efforts to prevent drug use through socialization among young people.
\end{abstract}

Keywords: Socialist, Drugs, Young People

Abstrak

Bahaya narkoba merupakan hal yang sangat nyata dimana ini sangat meresahkan kalangan termasuk guru atau dosen dari instansi pendidikan. Banyak anak muda yang menjdai korban dan bila dibiarkan maka akan merusak generasi muda yang pastinya akan mengancam kehidupan bangsa kedepannya. Pencegahan perlu dilakukan. Pengaruh penggunaan zat terlarang tersebut dapat memberbahayakan penggunanya baik bagi kesehatan tubuh maupun karater dan mental. Bahkan dapat menyebabkan kematian. Perlu adanya upaya mencari tahu mengapa penggunaan narkoba justru banyak dikalangan generasi muda atau para pelajar. Untuk itulah jurnal ini disusun dengan harapan dapat menjadi pendorong banyak pihak untuk melakukan upaya pencegahan penggunaan narkoba melalui sosialisasi di kalangan anak muda..

Kata kunci: Sosialisai, Narkoba, Anak Muda

\section{PENDAHULUAN}

Saat ini para orang tua, mulai dari ulama, guru/dosen, pejabat, penegak hukum dan bahkan semua kalangan telah resah terhadap narkoba. Sebab generasi muda masa depan bangsa telah banyak terlibat didalamnya. Akibatnya leluasanya penjualan narkoba ini, secara umum mengakibatkan timbulnya gangguan mental organic dan pergaulan bebas yang pada giliranya merusak masa depan bangsa. Penyalahgunaan narkotika dan obat - obatan terlarang di kalangan generasi muda dewasa ini kian meningkat. Maraknya penyimpangan perilaku generasi muda tersebut, dapat membahayakan keberlangsungan hidup bangsa ini di kemudian hari. Karena pemuda sebagai generasi yang diharapkan menjadi penerus bangsa.

Sebab penyalahgunaan narkoba ini telah merebak ke semua lingkungan, bukan hanya dikalangan anak-anak nakal dan preman tetapi telah memasuki lingkungan kampus dan lingkungan terhormat lainnya. Narkoba saat ini banyak kita jumpai di kalangan generasi muda dalam bentuk kapsul, tablet dan tepung seperti ekstasy, pil koplo dan shabu-shabu, bahkan dalam bentuk yang amat sederhana seperti daun ganja yang dijual dalam amplop - amplop. ${ }^{1}$

\footnotetext{
${ }^{1}$ Yususf Apandi, Katakan Tidak Pada Narkoba (Jakarta: Simbiosa Rekatama Media, 2010).
} 


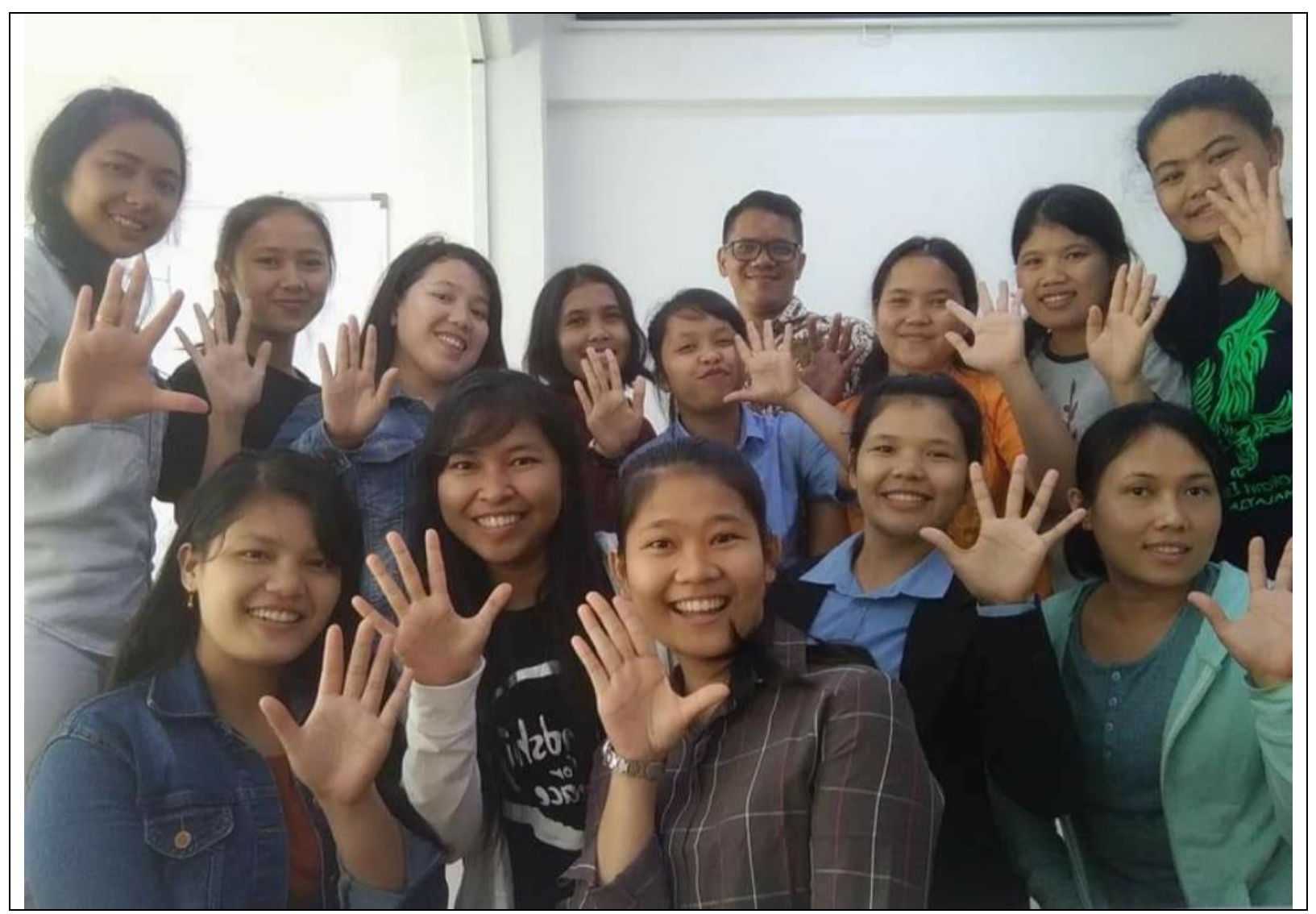

Gambar 1. Foto Bersama Generasi muda untuk katakan 'Say no to Drug'

\section{METODE}

Jurnal ini disusun dengan menggunakan Metode ceramah. Kegiatan dilaksanakan dengan menyebarkan flyer kegiatan ke sekolah - sekolah baik itu tingkat SMP dan SMK yang ada di Batam. Kegiatan ini untuk mengkampanyekan Remaja bebas dari penyalahgunaan narkoba, ataupun keluarga - keluarga yang memiliki anak beranjak dewasa untuk mensosialisasikan bahaya narkoba. Kegiatan ini sekaligus sebagai bentuk kampanye terbuka upaya dari Tim PKM STT Real Batam dalam mendukung program pemerintah untuk memberikan literasi Anti narkoba, bagi para pelajar sedini mungkin. Adapun Kegiatan ini dilaksanakan pada tanggal 10 Januari 2021.

\section{HASIL DAN PEMBAHASAN Isi Hasil dan Pembahasan}

Mengutip dari apa yang tertulis dalam web Badan Narkotika Nasional Republik Indonesaia bahwa yang dimaksud narkotika adalah zat atau obat yang berasal dari tanaman atau bukan tanaman, baik sintetis maupun semi sintetis yang dapat menyebabkan penurunan atau perubahan kesadaran, hilangnya rasa nyeri dan dapat menimbulkan ketergantungan. Sementara menurut UU Narkotika pasal 1 ayat 1 menyatakan bahwa narkotika merupakan zat buatan atau pun yang berasal dari tanaman yang memberikan efek halusinasi, menurunnya kesadaran, serta menyebabkan kecanduan. ${ }^{2}$

Di Indonesia, pencandu narkoba ini perkembangannya semakin pesat. Badan Nasional Narkotika (BNN) mencatat pengguna narkoba di Indonesia pada tahun 2017 mencapai 3,3 juta orang atau sebanyak 1,77 persen dari total penduduk Indonesia usia produktif. Angka ini didapat dari hasil

${ }^{2}$ Humas, "Pengertian Narkoba Dan Bahaya Narkoba Bagi Kesehatan," BNN, https://bnn.go.id/pengertian-narkoba-dan-bahaya-narkoba-bagi-kesehatan/. 
survei yang dilakukan BNN dengan Pusat Penelitian Kesehatan Universitas Indonesia pada tahun lalu. ${ }^{3}$ Rentang usia para pencandu narkoba itu pada umumnya berada antara 11 sampai 24 tahun. Dimana itu merupakan usia produktif di kalangan anak muda. Pada awalnya, para anak muda ini yang mengonsumsi narkoba biasanya mengawalinya dengan kebiasaan merokok. Sebagaimana diketahui bahwa merokok ini sepertinya sudah menjadi hal yang wajar di kalangan anak muda saat ini. Dari kebiasaan merokok inilah, pengaruh pergaulan terus meningkat, dimana para anak muda tersebut yang awalnya perokok terpengaruh menjadi pencandu narkoba. ${ }^{4}$

\section{Bahaya Narkoba Bagi Anak Muda}

Pada Tanggal 26 Juni 2006 lalu diperingati sebagai Anti Madat Sedunia. Didorong keprihatinan akan meningkatnya pengguna narkoba khususnya di kalangan anak muda, maka dengan diperingatinya Hari Anti Narkoba Internasional ini, dapat mencegah meluasnya pemakaian narkoba terutama dikalangan anak muda.

Masalah utama anak muda berawal dari pencarian jati diri. Mereka mengalami krisis identitas karena untuk dikelompokkan ke dalam kelompok anak-anak merasa sudah besar, namun kurang besar untuk dikelompokkan dalam kelompok dewasa. Hal ini merupakan masalah bagi setiap anak muda di belahan dunia ini.

Oleh karena pergumulan di masa muda ini, maka anak muda mempunyai kebutuhan sosialisasi yang seoptimal mungkin, serta dibutuhkan pengertian dan dukungan orangtua dan keluarga dalam kerentanan di masa muda.

Bila kebutuhan anak muda kurang diperhatikan, maka anak muda akan terjebak dalam perkembangan pribadi yang "lemah", bahkan dapat dengan mudah terjerumus ke dalam belenggu penyalahgunaan narkoba. Fraghini dalam tulisannya beta pentingnya tugas perkembangan bagi anak muda. Jika tugas perkembangan tidak dilewati dengan baik dapat mengakibatkan terbentuknya karakter atau perilaku yang menyimpang dan melanggar norma-norma sosial maupun agama. ${ }^{5}$

Hingga sekarang, penyalahgunaan narkoba semakin luas di masyarakat kita, terutama semakin banyak di kalangan anak muda yang sifatnya ingin tahu dan ingin coba-coba. Banyak alasan mengapa banyak yang terjerumus ke bahan terlarang dan berbahaya ini kemudian tidak mampu melepaskan diri lagi. Alasannya antara lain: (1). Dianggap sebagai gaya hidup masa ini. (2). Bujukan orang. (3). Ingin lari dari masalah yang ada (4). Ketergantungan dan tidak ada keinginan untuk berhenti.

Narkoba mempunyai pengaruh langsung pada tubuh Manusia adalah: (1). Gangguan pada jantung. (2) Gangguan pada hemoprosik. (3). Gangguan pada traktur urinarius. (4) Gangguan pada otak. (5). Gangguan pada tulang. (6). Gangguan pada pembuluh darah. (7) Gangguan pada endorin. (8) Gangguan pada kulit. (9). Gangguan pada sistem syaraf. (10). Gangguan pada paru-paru. (11). Gangguan pada sistem pencernaan. (11). Dapat terinfeksi penyakit menular berbahaya seperti HIV AIDS, Hepatitis, Herpes, TBC, dll. (12). Dan banyak dampak lainnya yang merugikan badan manusia.

Sedangkan pengaruh langsung Narkoba pada kejiwaan / Mental Manusia adalah: (1). Menyebabkan depresi mental. (2). Menyebabkan gangguan jiwa berat / psikotik. (3). Menyebabkan bunuh diri. (4). Menyebabkan melakukan tindak kejehatan, kekerasan dan pengrusakan. (5). Efek depresi bisa ditimbulkan akibat kecaman keluarga, teman dan masyarakat atau kegagalan dalam

\footnotetext{
${ }^{3}$ Erric Permana, "Pengguna Narkoba Indonesia 3,3 Juta Orang Di 2017," AA, last modified 2018, https://www.aa.com.tr/id/headline-hari/bnn-pengguna-narkoba-indonesia-3-3-juta-orang-di-2017-/1201940.

${ }^{4}$ Dadan Supardan, Meniti Masa Depan Menjauhi Narkoba (Jakarta Pusat: PT Mediantara Semesta, 2006).

${ }^{5}$ Chitra Fraghini, “Juvenile Delinquency Dalam Bentuk Penyalahgunaan Narkoba,” Mawa'Izh 10 no. 1, no. 77-95. (n.d.): 78.
} 
mencoba berhenti memakai narkoba. Namun orang normal yang depresi dapat menjadi pemakai narkoba karena mereka berpikir bahwa narkoba dapat mengatasi dan melupakan masalah dirinya, akan tetapi semua itu tidak benar. ${ }^{6}$

\section{Pencegahan Pemakaian Narkoba dikalangan Anak Muda}

Upaya pencegahan penyebaran narkoba di kalangan generasi muda sudah seharusnya menjadi tanggung jawab bersama, dalam hal ini semua pihak termasuk orang tua, guru, dan masyarakat harus turut berperan aktif dalam mewaspadai ancaman dari narkoba.

Adapun upaya - upaya lebih kongkret yang dapat dilakukan adalah melakukan kerja sama dengan pihak yang berwenang untuk melakukan penyuluhan tentang bahaya narkoba, atau mungkin mengadakan razia mendadak secara rutin. Kemudian pendampingan dari orang tua itu sendiri dengan memberikan perhatian dan kasih sayang.

Karakteristik psikologis yang khas pada anak muda merupakan faktor yang memudahkan terjadinya tindakan penyalahgunaan zat. Namun demikian, untuk terjadinya hal tersebut masih ada faktor lain yang memainkan peranan penting yaitu faktor lingkungan si pemakai zat. Faktor lingkungan tersebut memberikan pengaruh pada remaja dan mencetuskan timbulnya motivasi untuk menyalahgunakan zat. Salah satu yang paling berperan penting yaitu lingkungan keluarga. Oktir Nebi mengatakan ada dua cara pencegahan yang dapat dilakukan terhadap penyala gunaan narkoba. Pertama dengan sosialisasi, kedua dengan memberikan lingkungan yang kondusif bagi mereka tentunya hal ini dapat dicapai bila dimulai dari lingkungan keluarga. Alya Nurmaya mendukung bila lingkungan itu penting bagi anak muda terkait masalah narkoba. Namun Nurmaya lebih meyorot kepada lingkungan sekolah atau peranan guru. Bila Nebi berbicara mengenai lingkungan keluarga memiliki peran penting tentulah hal serupa berlaku dalam lingkungan sekolah. Fakta yang dapat kita lihat bahwa dimasa sekarang hampir Sebagian besar waktu yang dimiliki oleh Sebagian besar anak muda berada di lingkungan sekolah. Menurut Nurmaya keterlibatan anak muda dalam penggunaan zat terlarang itu diakibatkan oleh ketidak mampuan anak muda dalam berfikir positif. ${ }^{7}$

Dengan kata lain, timbulnya masalah penyalahgunaan zat dicetuskan oleh adanya interaksi antara pengaruh lingkungan dan kondisi psikologis anak muda tersebut. Di dalam upaya pencegahan, tindakan yang dijalankan dapat diarahkan pada dua sasaran proses. Pertama diarahkan pada upaya untuk menghindarkan generasi muda dari lingkungan yang tidak baik dan diarahkan ke suatu lingkungan yang lebih membantu proses perkembangan jiwanya. Upaya kedua adalah membantu generasi muda dalam mengembangkan dirinya dengan baik dan mencapai tujuan yang diharapkan (suatu proses pendampingan kepada si anak muda, selain: pengaruh lingkungan pergaulan di luar selain rumah dan sekolah). ${ }^{8}$

\section{Tindakan Pembimbingan Dan Pengarahan Perkembangan Anak Muda}

\section{Memberikan Pengetahuan Akan Bahaya Narkoba}

${ }^{6}$ Ahmadi Sofyan, Narkoba Mengincar Anak Anda Panduan Bagi Orang Tua, Guru, Dan Badan Narkotika Dalam Penanggulangan Bahaya Narkoba Di Kalangan Remaja. (Jakarta: Prestasi Pustaka Publisher, 2007).

${ }^{7}$ Alya Nurmaya, "Jurnal Psikologi Pendidikan \& Konseling PENYALAHGUNAAN NAPZA DI KALANGAN REMAJA," PENYALAHGUNAAN NAPZA DI KALANGAN REMAJA ( Studi Kasus Pada 2 Siswa Di MAN 2 Kota Bima) 2" no. 1, no. 26-32 (2016).

${ }^{8}$ Mangku et Al, "Pecegahan Narkoba Sejak Usia Dini (Jakarta: Badan Narkotika Nasional Republik Indonesia," (2007). 
Tentunya pengetahuan tentang narkoba itu penting untuk diberikan kepada anak-anak muda. Sebab di usia remaja beranjak dewasa adalah masa-masa seseorang ingin mencoba berbagai hal. Sebuah Jurnal dari fakultas ilmu kesehatan menunjukkan hasil dari penelitian mereka bahwa banyak anak-anak muda yang tidak memiliki pengetahuan tentang bahanya penggunaan narkoba. Kurangnya pengetahuan dikalangan anak muda mengakibatkan timbulnya rasa penasaran dan tindakan penyalahgunaan terhadap narkoba. ${ }^{9}$

Mellisa Fitri menuliskan bahwa penyalahgunaan narkoba dikalangan generasi muda-dewasa semakin meingkat setiap tahunnya. Lanjut dalam Fitri dikatan zat-zat yang terdapat dalam narkoba yang dikonsumsi dapat merusak saraf penggunanya. Fitri dalam tulisannya memaparkan jeni-jenis Narkoba beserta zat-zat yang terdapat didalamnya hingga cara penggunaannya. Tentunya hal itu bukan untuk mengajar kaum muda belajar menggunakan pemakaiannya, tetapi upaya agar kaum muda memahami dengan baik narkoba dan bahanya baik itu bagi fisik maupun mental dan karakter pengguna. ${ }^{10}$

\section{Memberikan Perhatian pada sikap dan tingkah laku}

Dari suatu perkembangan generasi muda secara umum adalah merubah sikap dan tingkah lakunya, dari cara yang kekanak-kanakan menjadi cara yang lebih dewasa. Sikap kekanak-kanakan seperti mementingkan diri sendiri (egosentrik), selalu menggantungkan diri pada orang lain, menginginkan pemuasan segera, dan tidak mampu mengontrol perbuatannya, harus diubah menjadi mampu memperhatikan orang lain, berdiri sendiri, menyesuaikan keinginan dengan kenyataan yang ada dan mengontrol perbuatannya sehingga tidak merugikan diri sendiri dan orang lain. Untuk itu dibutuhkan perhatian dan bimbingan dari pihak orang tua. Orang tua harus mampu untuk memberi perhatian, memberikan kesempatan untuk anak muda mencoba kemampuannya. Berikan penghargaan dan hindarkan kritik dan celaan.

\section{Membangun hubungan Emosional}

Untuk mendapatkan kebebasan emosional, anak muda mencoba merenggangkan hubungan emosionalnya dengan orang tua; ia harus dilatih dan belajar untuk memilih dan menentukan keputusannya sendiri. Usaha ini biasanya disertai tingkah laku memberontak atau membangkang. Dalam hal ini diharapkan pengertian orang tua untuk tidak melakukan tindakan yang bersifat menindas, akan tetapi berusaha membimbingnya secara bertahap.

\section{Mental-intelektual}

Dalam perkembangannya mental - intelektual diharapkan anak muda dapat menerima emosionalnya dengan memahami mengenai kelebihan dan kekurangan dirinya. Dengan begitu ia dapat membedakan antara cita-cita dan angan-angan dengan kenyataan sesungguhnya. Pada mulanya daya pikir generasi muda banyak dipengaruhi oleh fantasi, sejalan dengan meningkatnya kemampuan berpikir secara abstrak. Pikiran yang abstrak ini seringkali tidak sesuai dengan kenyataan yang ada dan dapat menimbulkan kekecewaan dan keputusasaan.

\section{Menciptakan lingkungan Sosial}

${ }^{9}$ and Neni Maemunah Restiara Wiyani, Atti Yudiernawati, "Pengaruh Pemberian Penyuluhan Terhadap Pengetahuan Pada Remaja Awal Tentang Bahaya Narkoba Di Man 1 Kelas X Malang,” Nursing News 2 no. 2 , no. 772-782 (2017).

${ }^{10}$ Mellisa Fitri and Sumringah Migunani, "Sosialisasi Dan Penyuluhan Narkoba,” Jurnal Inovasi Dan Kewirausahaan 3" no. 2, no. 72-76 (2014). 
Untuk mencapai tujuan perkembangan, generasi muda harus belajar bergaul dengan semua orang, baik teman sebaya atau tidak sebaya, maupun yang sejenis atau berlainan jenis. Adanya hambatan dalam hal ini dapat menyebabkan ia memilih satu lingkungan pergaulan saja misalnya suatu kelompok tertentu dan ini dapat menjurus ke tindakan penyalahgunaan zat. Sebagaimana kita ketahui bahwa ciri khas generasi muda adalah adanya ikatan yang erat dengan kelompoknya. Hal ini menimbulkan ide, bagaimana caranya agar generasi muda memiliki sifat dan sikap serta rasa (Citra: disiplin dan loyalitas terhadap teman, orang tua dan cita-citanya. Selain itu juga kita sebagai orang tua dan guru, harus mampu menumbuhkan suatu Budi Pekerti/Akhlaq yang luhur dan mulia; suatu keberanian untuk berbuat yang mulia dan menolong orang lain dan menjadi teladan yang baik.

\section{Pembentukan identitas diri}

Akhir daripada suatu perkembangan generasi muda adalah pembentukan identitas diri. Pada saat ini segala norma dan nilai sebelumnya merupakan sesuatu yang datang dari luar dirinya dan harus dipatuhi agar tidak mendapat hukuman, berubah menjadi suatu bagian dari dirinya dan merupakan pegangan atau falsafah hidup yang menjadi pengendali bagi dirinya. Orang tua memegang peranan penting dalam preoses identifikasi ini, karena mereka dapat membantu anak muda dengan menjelaskan secara lebih mendalam mengenai peranan agama dlam kehidupan dewasa, sehingga penyadaran ini memberikan arti yang baru pada keyakinan agama yang telah diperolehnya.

Yang paling penting adalah pengenalan diri sendiri dari pihak orang tua sebelum mereka mengharapkan generasi muda mengenal dirinya. Dengan kata lain, apa yang diharapkan dari generasi muda harus dapat dilaksanakan terlebih dahulu oleh orang tua dan guru, seperti beribadah dan mengunjungi tempat ibadah sesuai dengan iman kepercayaannya. ${ }^{11}$

\footnotetext{
${ }^{11}$ Kartini Kartono, Patologi Sosial II Kenakalan Remaja (Jakarta: Rajawali, 1992).
} 


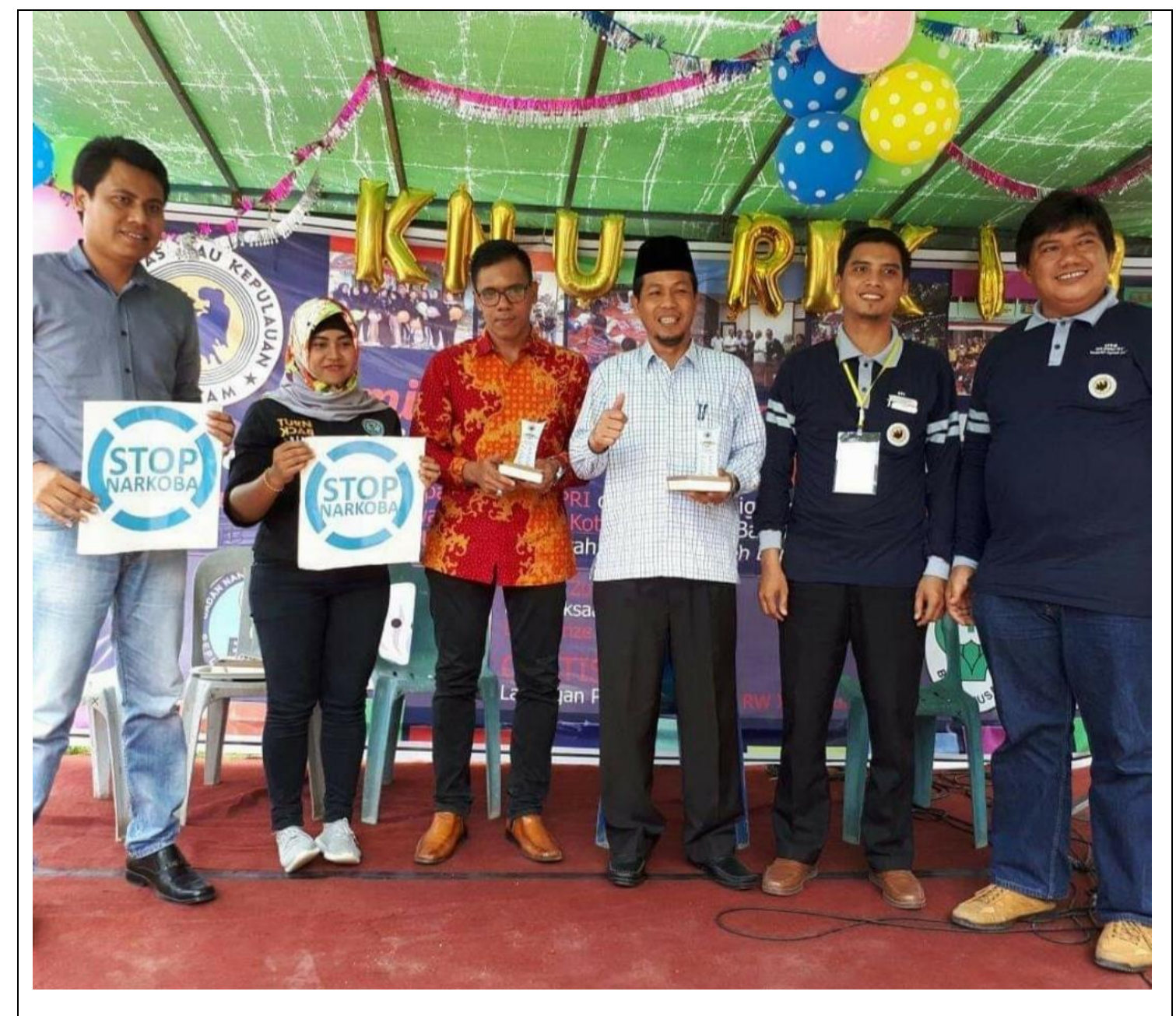

Gambar 2. Foto Bersama Panitia Penyelenggara Setelah Sosialisasi Bahaya Narkoba 


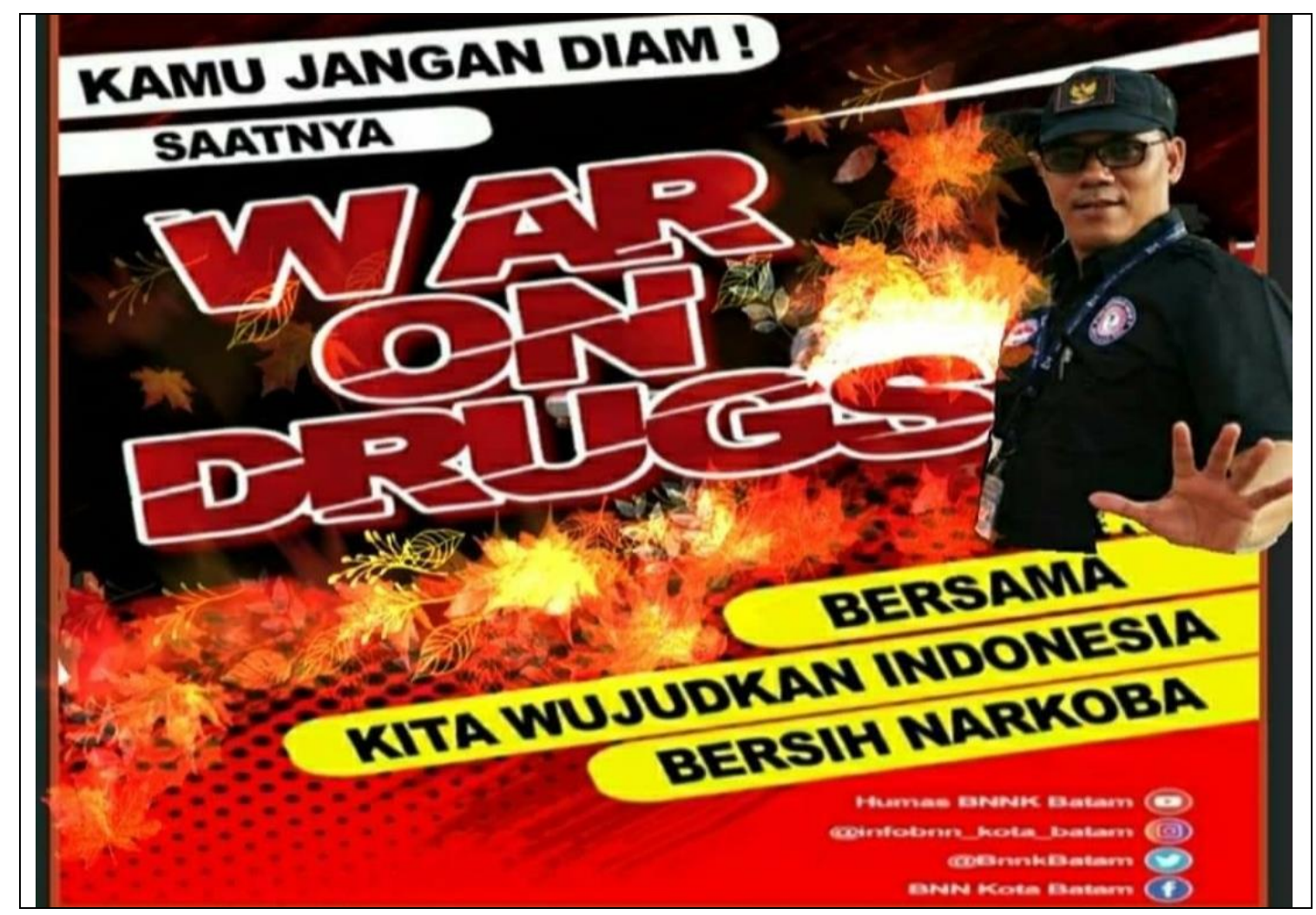

Gambar 3. E-flyer seruan untuk nyatakan perang terhadap narkoba

\section{SIMPULAN}

Dapat disimpulkan bahwa penggunaan Narkoba atau zat terlarang sangat berbahaya. Karena memberikan pengaruh buruk bagi kesehatan baik jasmani atapun kejiwaan bagi pemakainnya bahkan berpotensi pada kematian. Pengaruh lebih besar juga pada rusaknya generasi muda sebagai penerus bangsa. Kerusakan sistem saraf, perilaku dan mental pemakai pada anak-anak muda yang mengonsumsi zat-zat terlarang tersebut, maka akan berpotensi besar merusak generasi penersus bangsa.

Oleh karena itu anak muda membutuhkan lingkungan yang baik dalam keluarga maupun diluar dari keluarga yang dapat memberikan pengaruh positif bagi mereka. Lingkungan yang buruk serta kurangnya kemampuan anak-anak muda untuk berfikir positif dibarengi dengan ketidaktahuan akan bahaya zat terlarang membuat mereka terjerumus kedalam penyalahgunaan narkoba. Maka dari itu perlu adanya tindakan pencegahan berupa sosialisasi kepada anak-anak muda supaya mereka tidak terjerumus kedalam jerat narkoba. Dengan sosialisai bahaya narkoba bagi anak muda diharapkan dapat membekali mereka dengan pengetahuan sehingga dapat mereka mengambil pilihan untuk menghidari pemakaian narkoba dan memilih aktivitas-aktivitas yang positif dalam mengekspresikan kehidupanan anak muda.

\section{DAFTAR PUSTAKA}

Al, Mangku et. "Pecegahan Narkoba Sejak Usia Dini (Jakarta: Badan Narkotika Nasional Republik Indonesia," (2007).

Apandi, Yususf. Katakan Tidak Pada Narkoba. Jakarta: Simbiosa Rekatama Media, 2010.

Fraghini, Chitra. "Juvenile Delinquency Dalam Bentuk Penyalahgunaan Narkoba." Mawa'Izh 10 no. 1, no. 77-95. (n.d.): 78.

Humas. "Pengertian Narkoba Dan Bahaya Narkoba Bagi Kesehatan." BNN. https://bnn.go.id/pengertian-narkoba-dan-bahaya-narkoba-bagi-kesehatan/.

Kartono, Kartini. Patologi Sosial II Kenakalan Remaja. Jakarta: Rajawali, 1992. 
Migunani, Mellisa Fitri and Sumringah. "Sosialisasi Dan Penyuluhan Narkoba," Jurnal Inovasi Dan Kewirausahaan 3" no. 2, no. 72-76 (2014).

Nurmaya, Alya. "Jurnal Psikologi Pendidikan \& Konseling PENYALAHGUNAAN NAPZA DI KALANGAN REMAJA," PENYALAHGUNAAN NAPZA DI KALANGAN REMAJA ( Studi Kasus Pada 2 Siswa Di MAN 2 Kota Bima) 2" no. 1, no. 26-32 (2016).

Permana, Erric. "Pengguna Narkoba Indonesia 3,3 Juta Orang Di 2017." AA. Last modified 2018. https://www.aa.com.tr/id/headline-hari/bnn-pengguna-narkoba-indonesia-3-3-juta-orang-di2017-/1201940.

Restiara Wiyani, Atti Yudiernawati, and Neni Maemunah. "Pengaruh Pemberian Penyuluhan Terhadap Pengetahuan Pada Remaja Awal Tentang Bahaya Narkoba Di Man 1 Kelas X Malang." Nursing News 2 no. 2, no. 772-782 (2017).

Sofyan, Ahmadi. Narkoba Mengincar Anak Anda Panduan Bagi Orang Tua, Guru, Dan Badan Narkotika Dalam Penanggulangan Bahaya Narkoba Di Kalangan Remaja. Jakarta: Prestasi Pustaka Publisher, 2007.

Supardan, Dadan. Meniti Masa Depan Menjauhi Narkoba. Jakarta Pusat: PT Mediantara Semesta, 2006. 